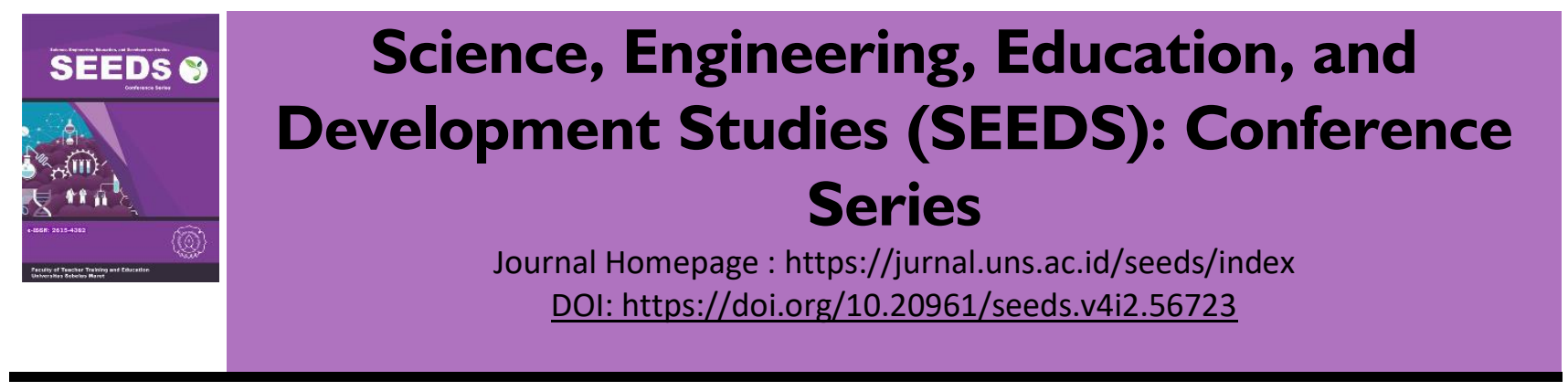

\title{
PEMANFAATAN MEDIA MODUL UNTUK MEMBANTU PEMBELAJARAN MICROSOFT WORD PADA SISWA BERKEBUTUHAN KHUSUS KELAS X DI SLB NEGERI BALIKPAPAN
}

Novita Febriani

SLB Negeri Balikpapan

viosmile1982@gmail.com

Article Info :

Available online $26 / 11 / 2021$

\section{Keywords:}

Media pembelajaran

tunagrahita

Anak berkebutuhan khusus

Modul pembelajaran

\begin{abstract}
Abstrak
Media pembelajaran sebagai alat bantu untuk mewujudkan situasi belajar mengajar yang efektif dan untuk meningkatkan mutu belajar peserta didik. Kajian ini bertujuan (1) memfasilitasi peserta didik secara visual dalam pembelajaran komputer (2) upaya untuk mengoptimalkan penyerapan informasi secara konkret bagi anak berkebutuhan khusus dalam pembelajaran komputer. Kurangnya ketersediaan bahan ajar yang sesuai dengan kebutuhan anak berkebutuhan khusus dalam mata pelajaran keterampilan komputer membuat tenaga pengajar harus berinovasi dengan bahan ajar dari sekolah umum. Dikembangkanlah modul pembelajaran ini guna mengatasi permasalahan yang dialami pengajar dan peserta didik..Hasil kajian ini diharapkan dapat menjadi patokan tenaga pengajar dalam menyampaikan materi pada peserta didik dan dapat meningkatkan kemampuan keterampilan dalam pembelajaran keterampilan komputer peserta didik di SLB Negeri Balikpapan.
\end{abstract}




\section{PENDAHULUAN}

Sekolah sebagai lembaga formal yang diserahi misi pendidikan. Peran sekolah sebagai sarana interaksi antar siswa begitu penting sehingga tidak jarang siswa menganggap bahwa pelajaran adalah gurunya, sehingga guru selalu menganggap pelajaran itu menarik bagi siswa. Cukup, tidak berguna, itu bukan aturan. Guru perlu dididik. Dengan kata lain, guru harus membesarkan siswa untuk menjadi orang dewasa yang bertanggung jawab. Hanya dengan cara ini semua aspek kepribadian siswa dapat dikembangkan.

Menurut Miarso (2004), media pembelajaran dapat digunakan untuk menyampaikan pesan yang diajarkan sehingga dapat merangsang perhatian, emosi, dan keterampilan siswa untuk memperlancar proses pembelajaran. Dalam mengkomunikasikan pesan yang diajarkan guru memerlukan sebuah perantara agar pesan dapat tersampaikan dengan baik. Oleh karena itu guru membutuhkan media yang efektif serta efisien. Media dalam proses pembelajaran merupakan perantara atau rujukan kepada pengirim pesan dengan cara merangsang pikiran, emosi, perhatian, dan persiapan sehingga penerima pesan terdorong dan terlibat dalam pembelajaran. Media yang digunakan untuk pembelajaran disebut media pembelajaran karena proses pembelajaran pada dasarnya juga merupakan proses komunikasi. Menurut pendapat Gagne and Briggs (1974) media pembelajaran merupakan alat yang digunakan untuk menyampaikan isi materi pembelajaran yang dapat merangsang siswa dalam mengikuti proses pembelajaran sejalan dengan pendapat Haryoko (2012) media pembelajaran umumnya didefinisikan sebagai alat, metode, dan teknik yang digunakan untuk memfasilitasi komunikasi dan interaksi antara guru dan siswa dalam proses pendidikan yang lebih efektif. Oleh karena itu, media pendidikan merupakan bagian integral dari proses pendidikan dan merupakan aspek yang harus dikuasai guru dalam menjalankan fungsi profesionalnya.

Kegiatan pembelajaran khususnya bagi anak yang berkebutuhan khusus membutuhkan media pembelajaran sebagai alat bantu dalam mengajar, media pembelajaran diharapkan dapat memberikan pengalaman konkret, motivasi belajar, mempertinggi daya serap dan prestasi belajar peserta didik.

Salah satu ABK adalah Anak tunagrahita ringan adalah salah satu golongan anak tunagrahita yang tarafnya masih ringan, serta masih memiliki kemampuan untuk di didik secara sederhana. Menurut pendapat Bratanata (1997) anak tunagrahita ringan adalah mereka yang masih mampu menempuh pendidikan akademik dan berkesempatan mempelajari keterampilan sederhana kelas dasar empat atau lima sekolah dasar. Menurut Munzayanah (2000) ciri-ciri atau karakteristik anak tunagrahita ringan adalah mereka dapat dilatih untuk pekerjaan ringan dan mereka memiliki kemampuan intelektual yang terbatas, sehingga mereka hanya dapat dilatih menulis, membaca dan berhitung sampai batas tertentu mengenai aktivitas dan keterampilannya sehari-hari juga dapat dilatih aktivitas dan keterampilan yang rutin. Menurut Amin (1995) anak-anak tunagrahita ringan mengalami kesulitan dalam berpikir abstrak dan dapat mengambil pelajaran akademis baik di sekolah umum maupun sekolah khusus. Sebagai aturan, seorang anak berusia 16 tahun hanya secerdas anak berusia 12 tahun.

Tenaga pendidik memiliki banyak pilihan media pembelajaran. Penggunaan media pembelajaran perlu disesuaikan dengan kebutuhan anak dan perkembangan teknologi modern saat ini. Media memiliki fungsi yang sangat besar dalam kegiatan pembelajaran, dan sebagai fasilitator untuk menyampaikan dan menyebarkan ide, gagasan, dan pendapat selama pembelajaran, guru atau pengajar dapat menyampaikan apa yang mereka sampaikan kepada peserta didik. Salah satu bahan ajar yang digunakan oleh guru khususnya pendidik di lingkungan pendidikan adalah modul pembelajaran yang tersusun secara sistematis yang dicetak kemudian dijadikan pedoman bagi pendidik dan peserta didik. Modul pembelajaran sesuai yang disampaikan Prastowo (2012) menjelaskan pengertian modul pembelajaran sebagai bahan ajar yang memiliki empat fungsi, termasuk fungsi sebagai pengganti guru. Artinya, isi modul pembelajaran harus menjelaskan materi secara lengkap, jelas, dan tentunya secara terstruktur. Bahan ajar mandiri yang dibaca dan dipahami oleh siswa yang belajar secara intensif perlu dapat berfungsi secara mandiri bagi banyak siswa, menjadi media evaluasi pembelajaran, dan dipahami oleh siswa. Dengan modul pembelajaran, guru dapat mengetahui apakah keterampilan peserta didik telah meningkat atau pemahaman tentang materinya buruk, jadi perlu meningkatkannya.

Sementara itu, permasalahan yang masih sering ditemui pada Sekolah Luar Biasa (SLB) selain media pembelajaran juga masih minim, buku teks pembelajaran juga masih terbatas khususnya di mata pelajaran komputer yang tidak tersedia, hal ini yang membuat pembelajaran komputer belum mencapai hasil yang maksimal. Hal ini terbukti pada setiap pembelajaran komputer pendidik memberikan pembelajaran yang tidak sesuai dengan Kurikulum hanya memberikan tugas/pembelajaran untuk memberikan kesibukkan pada peserta didik saja. Pada saat ujian sekolah dengan tes tertulis, peserta didik kesulitan dalam menjawab soal dengan tepat sehingga nilai yang di peroleh masih di bawah KKM. 
Berdasarkan permasalahan di atas, diperlukan perubahan pada metode pembelajaran dan media pembelajaran yang digunakan sehingga pembelajaran menjadi terarah sehingga dapat meningkatkan kemampuan peserta didik dalam keterampilan pembelajaran komputer dan meningkatkan pemahaman peserta didik sehingga mampu menjawab tes tertulis dengan tepat dan mandiri.

Salah satu cara untuk meningkatkan pemahaman dan hasil belajar siswa dengan mengembangkan bahan ajar yang baik menurut Purwanto, Aristo Rahadi, and Lasmono (2007) adalah dengan menggunakan modul. Modul adalah bahan pembelajaran yang disusun secara sistematis menurut kurikulum tertentu, dikemas dalam satuan pembelajaran terkecil, dan memungkinkan pembelajaran mandiri dalam satuan waktu tertentu. Menurut Kependidikan (2015) modul adalah bahan tercetak yang perlu dipelajari sendiri oleh peserta didik. Modul juga dikenal sebagai media belajar mandiri karena dilengkapi dengan instruksi belajar mandiri. Namun, ada banyak modul di pasaran yang tidak mendukung kurikulum anak berkebutuhan khusus. Hal ini mengakibatkan ketersediaan bahan ajar tersebut yang dalam hal ini berupa modul perlu dikembangkan sebagaimana mestinya karena masih terbatas untuk anak berkebutuhan khusus. Berdasarkan uraian diatas bahwa media modul pembelajaran adalah suatu cara yang dapat digunakan guru untuk mengatasi permasalahan yang dialami peserta didik selama ini sehingga dapat mendukung kegiatan pembelajaran komputer di SLB Negeri Balikpapan.

\section{HASIL DAN PEMBAHASAN}

\section{Pengertian Modul}

Prastowo (2012) berpendapat, modul merupakan bahan ajar yang disusun secara sistematis dengan bahasa yang mudah dipahami oleh siswa, sesuai usia dan tingkat pengetahuan mereka agar mereka dapat belajar secara mandiri dengan bimbingan minimal dari pendidik. Penggunaan modul dalam pembelajaran bertujuan agar siswa dapat belajar mandiri tanpa atau dengan minimal dari guru. Di dalam pembelajaran, guru hanya sebagai fasilitator. Pandangan serupa juga dikemukakan oleh Sukiman (2011) yang menyatakan bahwa modul adalah bagian kesatuan belajar yang terencana yang dirancang untuk membantu siswa secara individual dalam mencapai tujuan belajarnya. Siswa yang memiliki kecepatan tinggi dalam belajar akan lebih cepat menguasai materi. Sementara itu, siswa yang memiliki kecepatan rendah dalam belajar bisa belajar lagi dengan mengulangi bagian-bagian yang belum dipahami sampai paham. Menurut Rudi Susilana and Riyana (2008) modul merupakan suatu paket program yang disusun dan didesain sedemikian rupa untuk kepentingan belajar siswa. Pendekatan dalam pembelajaran modul menggunakan pengalaman siswa. Berdasarkan pendapat di atas, ada beberapa hal penting dalam mendefinisikan sebuah modul. Artinya, bahan belajar mandiri yang membantu siswa mencapai tujuan belajar mereka, dan paket program yang dirancang untuk memfasilitasi pembelajaran mereka. Dari sini, kita dapat menyimpulkan bahwa modul ini adalah bahan pembelajaran yang berdiri sendiri, paket program yang terstruktur dan dirancang untuk membantu siswa mencapai tujuan belajar mereka. Oleh karena itu, siswa dapat belajar dengan kecepatan mereka sendiri.

\section{Karakteristik modul}

Menurut Kejuruan (2008), modul yang dikembangkan perlu memperhatikan lima karakteristik modul: belajar mandiri, mandiri, berdiri sendiri, adaptif, dan ramah pengguna. 1) Belajar mandiri, siswa dapat belajar secara mandiri dan tidak bergantung pada orang lain, dapat melakukan belajar mandiri jika modulnya adalah: Termasuk tujuan pembelajaran yang jelas. Materi pembelajaran dikemas dalam unit kegiatan kecil/tertentu. Tersedianya contoh dan ilustrasi untuk membantu memperjelas penyajian materi pembelajaran. Ada pertanyaan, tugas, dll untuk latihan. Konteks; Bahasanya sederhana dan komunikatif. Adanya rangkuman materi pembelajaran; Adanya alat penilaian diri (self-assessment); Adanya umpan balik terhadap penilaian siswa. Dan informasi tentang referensi. 2) Mandiri, semua bahan pembelajaran yang diperlukan sudah termasuk dalam modul. Fitur-fitur ini memberi siswa kesempatan untuk mempelajari subjek secara menyeluruh. 3) Modul yang berdiri sendiri dan dikembangkan tidak bergantung pada bahan lain atau tidak perlu digunakan dengan bahan lain. Siswa tidak memerlukan bahan lagi untuk mempelajari atau mengerjakan modul. 4) Modul adaptif bersifat adaptif terhadap perkembangan ilmu pengetahuan dan teknologi serta memiliki fleksibilitas untuk digunakan pada berbagai perangkat keras. Modul adaptif adalah ketika modul dapat digunakan untuk jangka waktu tertentu. Modul ramah pengguna (ramah / akrab) berisi penjelasan dan penyajian informasi yang sederhana dan mudah dipahami menggunakan istilah yang sering 
digunakan. Menggunakan bahasa yang sederhana dan menggunakan istilah umum merupakan bentuk kemudahan penggunaan.

\section{Sistematika Modul}

Modul ini berjudul " Modul pembelajaran Microsoft Word 2010 Tunagrahita kelas X SMALB Negeri Balikpapan", memuat contoh-contoh latihan penggunaan menu dan toolbar pada aplikasi Ms. Word 2010, di susun berdasarkan kemampuan peserta didik di Sekolah Luar Biasa Negeri Balikpapan (SLBN Balikpapan), dapat dipakai untuk peserta didik tunagrahita ringan, autism, tunarungu dan tuna daksa dengan minimal kemampuan peserta didik mampu membaca dan menulis. Modul ini ada 25 halaman dimulai dari kegiatan belajar 1 sampai kegiatan belajar 16 setiap kegiatan belajar disertai dengan materi dan langkah detail yang harus dikerjakan, disusun sangat sederhana sehingga mudah dipahami oleh peserta didik berkebutuhan khusus. Dibagian akhir modul disertai dengan tugas praktek dan tugas sumatif untuk mengukur hasil dan kemampuan belajar peserta didik.

1. Bagian pembuka

Bagian pembuka terdiri dari pendahuluan, uraian singkat isi modul, kriteria kemampuan (SK) dan kemampuan dasar (KD), peta konsep, keunggulan modul, penjelasan cara penggunaan modul, tujuan pembelajaran dan topik.

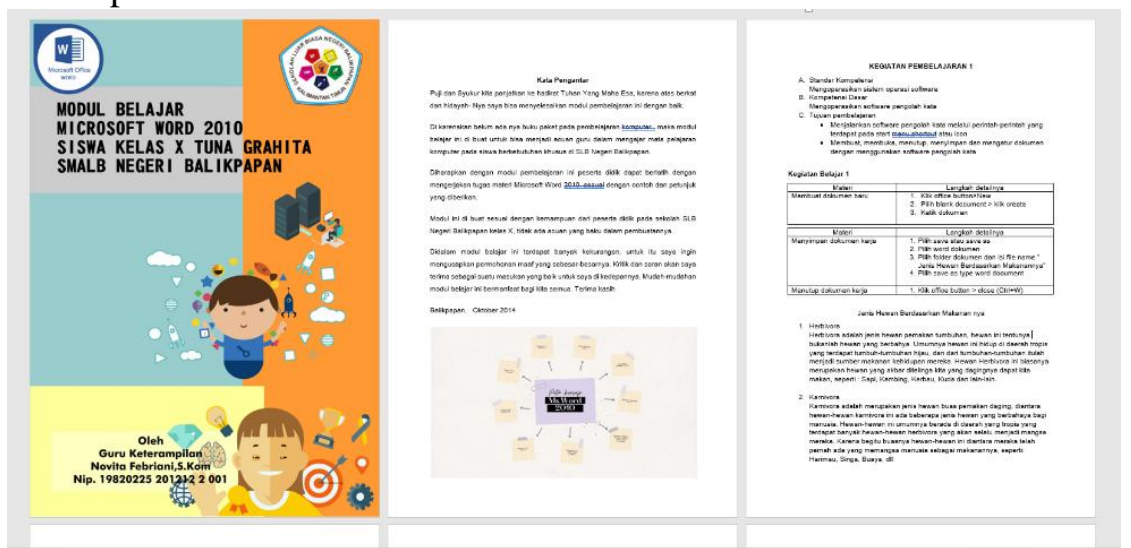

Gambar 1. Pendahuluan, isi modul, SK, KD, peta konsep, keunggulan, cara penggunaan modul, tujuan pembelajaran dan topik

2. Bagian Inti

Bagian inti terdiri dari kegiatan belajar 1,2,3...dst

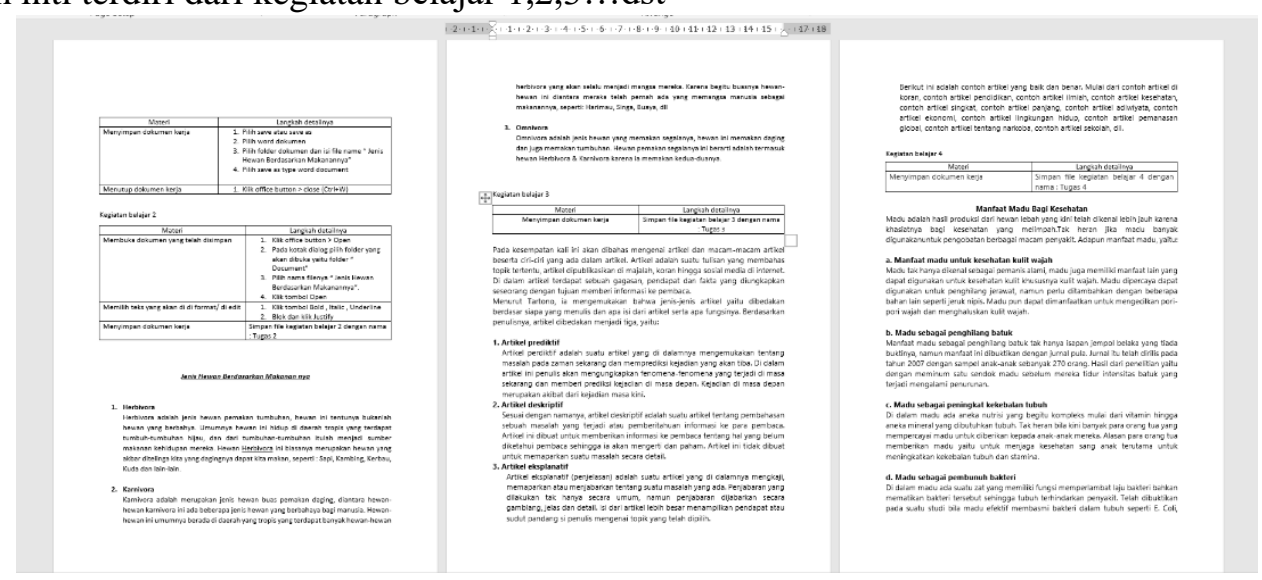

Gambar 2. Bagian inti yang terdiri dari kegiatan belajar 


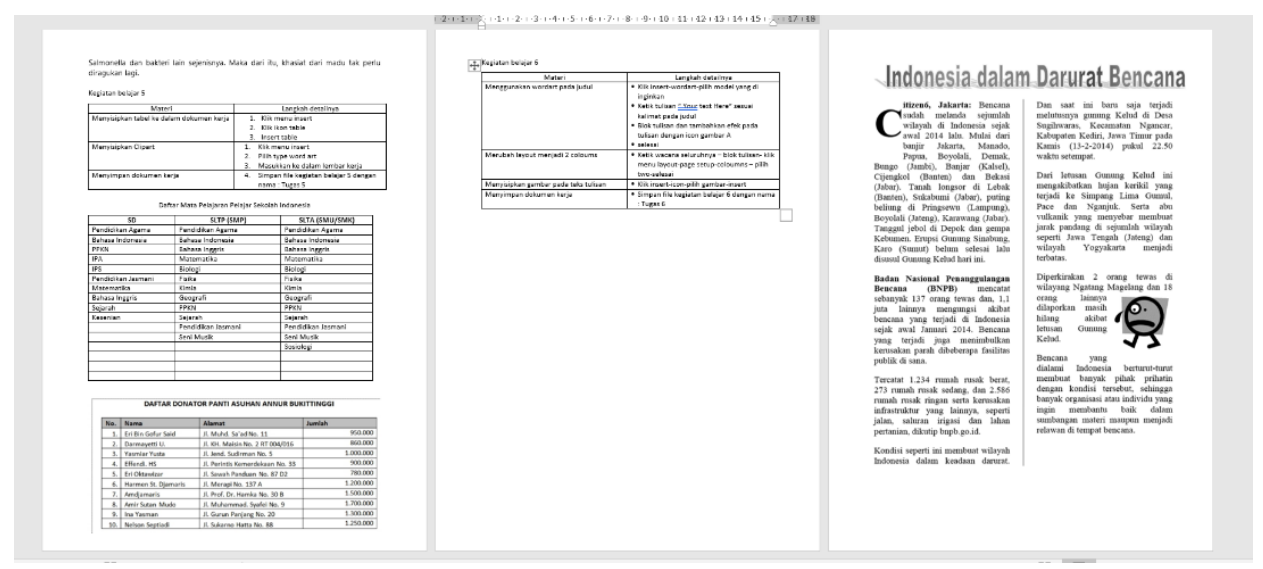

Gambar 3. Bagian inti yang terdiri dari kegiatan belajar (2)

3. Bagian Penutup

Bagian penutup terdiri dari evaluasi sumatif, petunjuk penilaian,kunci jawaban

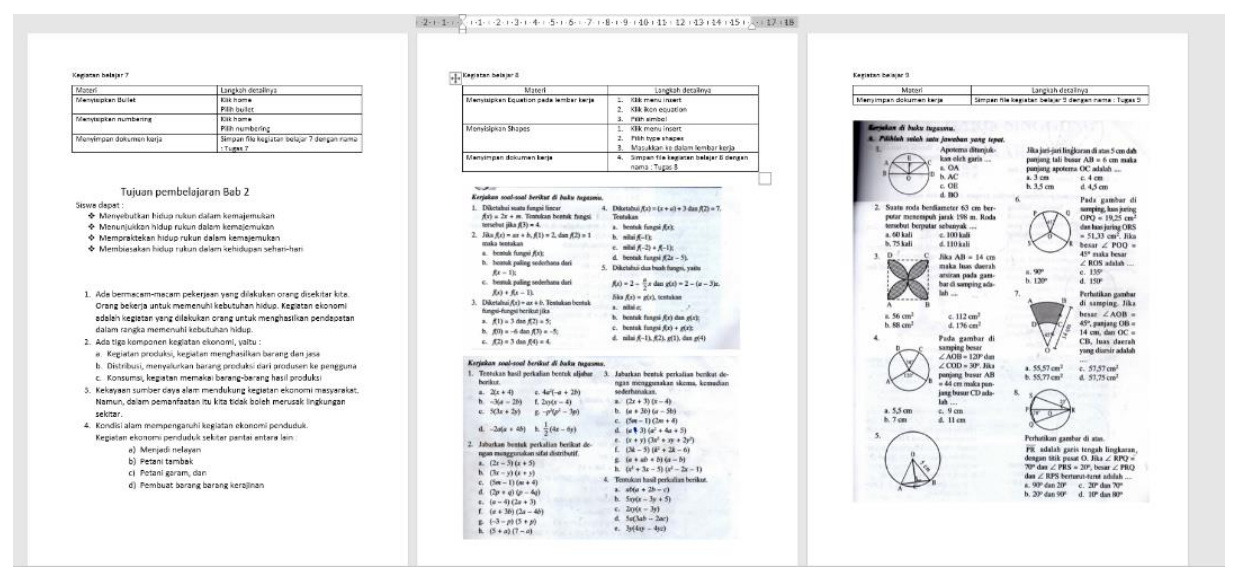

Gambar 4. Bagian penutup yang terdiri dari evaluasi sumatif, petunjuk penilaian,kunci jawaban

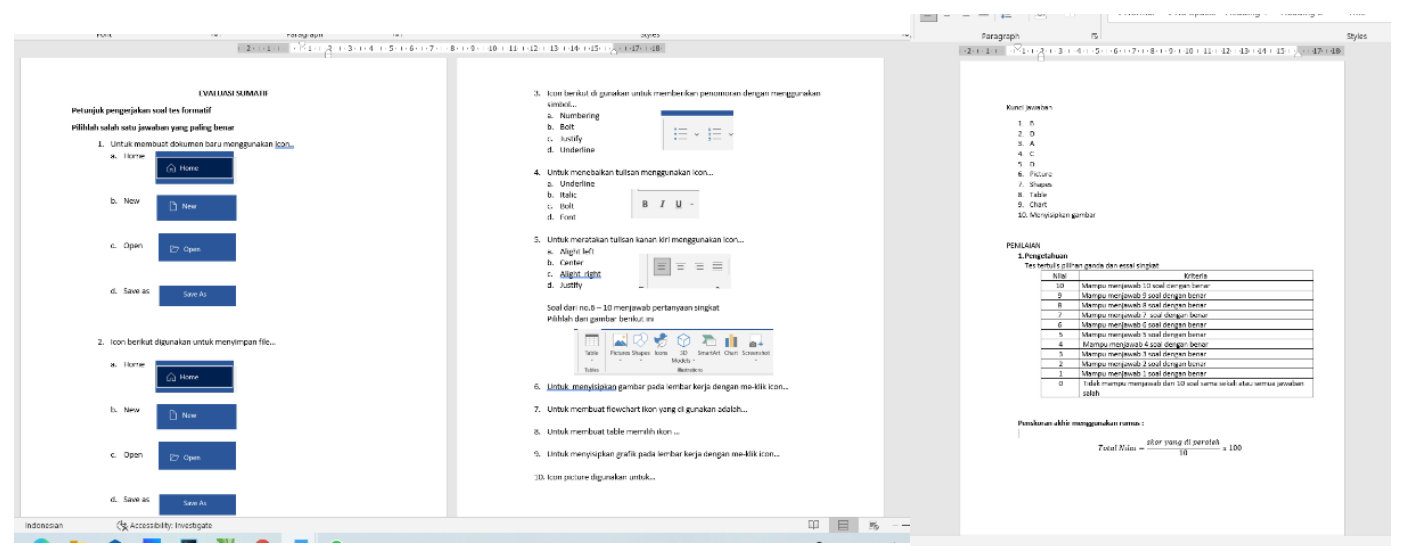

Gambar 5. Bagian penutup yang terdiri dari evaluasi sumatif, petunjuk penilaian,kunci jawaban (2)

\section{KESIMPULAN}

Dengan adanya modul ini pendidik mempunyai acuan, tujuan, patokan dalam mengajar keterampilan komputer di kelas, memudahkan dalam menilai kemampuan masing-masing peserta didik, bagi peserta didik pembelajaran menjadi berpola bisa punya pandangan hari ini akan belajar apa dan setelah pertemuan hari ini selanjutnya pertemuan berikutnya akan belajar apa. Untuk beberapa peserta didik autis dengan modul ini pembelajaran membantu pemahaman mereka secara visual. Dimana hambatan dari autism tidak merespon 
instruksi dan uraian secara verbal. peserta didik dapat menilai kemampuan nya sendiri pada kegiatan belajar ke berapa yang sulit bagi mereka. Dengan modul ini peserta didik menjadi mandiri walaupun tidak di dampingi guru mereka sudah tau apa yang harus mereka lakukan ketika berada di dalam kelas. Peserta didik menjadi teliti karena dengan modul ini mereka membaca dan mengamati simbol yang ada pada modul.

Media pembelajaran dengan modul ini salah satu solusi yang berhasil untuk pembelajaran komputer bagi siswa berkebutuhan khusus di SLBN Balikpapan, modul pembelajaran menjadikan pembelajaran menjadi terarah sehingga dapat meningkatkan kemampuan, keterampilan komputer peserta didik dan meningkatkan pemahaman peserta didik dalam menjawab tes tertulis dengan tepat dan mandiri. Di sarankan untuk penelitian selanjutnya dilakukan ujicoba dengan pendekatan dan presentase ketuntasan.

\section{DAFTAR PUSTAKA}

Amin, M. (1995). Ortopedagogik Anak Tunagrahita. Jakarta: Direktorat Jendral Pendidikan Depdikbud.

Bratanata, S. A. (1997). Pendidikan Anak Terbelakang Mental. Jakarta: Depdikbud.

Gagne, R. M., \& Briggs, L. J. (1974). Principles of instructional design: Holt, Rinehart \& Winston.

Haryoko, S. (2012). Efektivitas pemanfaatan media audio-visual sebagai alternatif optimalisasi model pembelajaran. Jurnal Edukasi Elektro, 5(1).

Kejuruan, D. P. S. M. (2008). Bahan Bimbingan Teknis Peningkatan Mutu Pembelajaran SMK Seri Pelaksanaan Prakerin. Jakarta: Departemen Pendidikan Nasional.

Kependidikan, P. M. P. d. T. (2015). DIREKTORAT JENDERAL PENINGKATAN MUTU PENDIDIK DAN TENAGA KEPENDIDIKAN DEPARTEMEN PENDIDIKAN NASIONAL.

Miarso, Y. H. (2004). Menyemai Benih Teknologi Pendidikan. Jakarta: Prenoda Media.

Munzayanah. (2000). Tunagrahita. UNS Surakarta: Depdikbud.

Prastowo, A. (2012). Panduan Kreatif Membuat Bahan Ajar Inovatif: Menciptakan Metode Pembelajaran yang Menarik dan Menyenangkan. Yogyakarta: Diva Press.

Purwanto, Aristo Rahadi, \& Lasmono, S. (2007). Pengembangan Modul. Jakarta: Pusat Teknologi Informasi dan Komunikasi Pendidikan (PUSTEKKOM) Depdiknas.

Rudi Susilana, \& Riyana, C. (2008). Media Pembelajaran. Yogyakarta: CV Wacana Prima.

Sukiman. (2011). Pengembangan Media Pembelajaran. Yogyakarta: Pustaka Insan Madani. 